\title{
COMPARISON OF THE TERMS CREATIVE ACCOUNTING, EARNINGS MANAGEMENT AND FRAUDULENT ACCOUNTING THROUGH BIBLIOGRAPHIC ANALYSIS
}

\author{
Roman Hlawiczka ${ }^{1, a}$, Roman Blazek ${ }^{2, b, *}$, Gabriele Santoro ${ }^{3, c}$ and Gianluca \\ Zanellato $^{4, d}$
}

${ }^{1}$ Silesian University in Opava, School of Business Administration in Karviná, Department of Finance and Accounting, Univerzitní náměstí 1934/3, Karviná, Czech Republic

${ }^{2}$ Faculty of Operation and Economics of Transport and Communications, Department of Economics, University of Zilina, Univerzitna 1, 01026 Zilina, Slovak Republic

${ }^{3}$ Department of Management, University of Turin, Via Verdi, 8 - 10124, Turin, Italy

${ }^{4}$ Faculty of Economics and Business Administration, Babeș-Bolyai University, Strada Teodor Mihali, Nr. 58-60, 400591, Cluj-Napoca, Romania

aroman.hlawiczka@opf.slu.cz, broman.blazek@stud.uniza.sk, 'cgabriele.santoro@unito.it, dgianluca.zanellato@econ.ubbcluj.ro

*Corresponding author

Cite as: Hlawiczka, R., Blazek, R., Santoro, G., Zanellato, G. (2021). Comparison of the terms creative accounting, earnings management and fraudulent accounting through bibliographic analysis, Ekonomicko-manazerske spektrum, 15(2), 27-37.

Available at: dx.doi.org/10.26552/ems.2021.2.27-37

Received: 28 June 2021; Received in revised form:20 August 2021; Accepted: 9 September 2021; Available online: 30 December 2021

\begin{abstract}
:
Research background: The article focuses on the issues of creative accounting, earnings management, and fraudulent accounting, which are global phenomena. These concepts are well known globally, as they are dealt with by many world-renowned authors. In this study, we applied bibliometric analysis to these concepts to reveal their interconnectedness. The research was conducted on a sample of more than 19,000 articles.

Purpose of the article: The main goal of the study is to use the VosViewer design and visualisation program to capture and record the most common terms associated with the terms, 'creative accounting', 'revenue management', and 'fraudulent accounting', and to show a biometric network of the most commonly used terms.

Methods: To capture and illustrate important words associated with the above terms, the VosViewer program was used, which drew mind maps that represented the words and expressions that were closest to the topic. Scientific articles from the Web of Science database, which contains many world-class articles related to the topic, were used as input data.

Findings \& Value added: The results of the study provided an interesting insight into the keywords associated with the issues of creative accounting, revenue management, and fraudulent accounting. The results show that the keywords and phrases are related, as several of them are repeated in each of the terms mentioned. This means that, although these terms are different in nature, they are nevertheless connected by many words and phrases. However, it remains necessary to observe that each of the given terms appears on a different colour of fraud (white, grey, or black fraud).
\end{abstract}


Keywords: Bibliometric analysis, Earnings management, Creative accounting, Fraudulent accounting

\section{JEL Classification: M21, O32}

\section{Introduction}

Accounting, as the most comprehensive economic information system, is supposed to present a true and fair view of the property, income, and financial position of a company. Creative accounting, inversely, aims to creatively adjust a company's results to a desired form, which means that it can affect a company's final value (Adamikova and Corejova, 2021), thus favouring such a company (Kovalova and Michalkova, 2020) over other economic entities. Creative accounting can influence the choice of method of depreciation or valuation of assets, a company's budgetary policy for the next years (Milesi-Ferretti, 2004), or the resulting value of its creditworthiness or the prediction of the company's bankruptcy (Nyvltova, 2016). Although creative accounting might sound as if it were an unknown concept, which would be a case of ignotum per ignotum, it is not a modern phenomenon (Zemankova, 2015). The first mention of creative accounting dates back to the Middle Ages; nevertheless, the phenomenon remains without a permanent place in the literature. However, the concept has begun to draw increasing attention (Zemankova, 2015), as evidenced by the growing number of scientific articles that attempt to understand it and reach many scientists who deal with the issue or would deal with it if they wanted to.

Economic crime is associated with creative accounting, which is caused by, for example, tax optimisation (Luty, 2019). We can understand economic crime as a special category of crime with an increasing tendency. Various worldwide surveys report large business losses due to economic crime. We are in an advanced age, which brings with it many technological and information conveniences that contribute to more comprehensive detection and reduction of economic fraud. This encourages many businesses, globally, to resort to fraud, which ultimately affects the entire business environment. The environment then falls victim to dishonest entrepreneurs, such as creative accountants, managers, and business owners, who crave wealth. Such creative errors and fraud in accounting bear serious consequences for the management of companies (Kouriliva and Stejskalova, 2015).

However, many scientists are fighting this global phenomenon, which is spreading like a virus to all countries, threatening businesses. To combat the use of creative accounting, it is necessary to identify not only the external factors that motivate companies to adopt it, but also internal ones (Zemankova, 2015), which are as critical for understanding the overall behaviour associated with the phenomenon. Several models are frequently used to detect the use of creativity in accounting. However, these models are not always applicable to the accounting standard regime in the country under study; therefore, scientists create their own models that are based, for instance, on the principle of logistic regression (Sylwestrzak, 2016).

Accounting fraud cases continue to increase; therefore, we created a bibliometric analysis to help researchers navigate the landscape of manipulations and number of articles that exist to find appropriate terms or keywords in order to obtain desired results.

\subsection{Literature review}

An interesting perspective on valuation accounting is offered by Merchant and Rockness (2004), who assert that valuation accounting can affect a company's economic results, although it may not be economical for the company; on the contrary, it may be detrimental to the company in the long run. Veiga et al. (2004) remind us that we cannot understand creative 
accounting only in a negative light, consistent with Merchant and Rockness's view. However, an important finding in this study is that an organisation can improve its results without necessarily jeopardising the purpose of accounting. In this case, the organisation complies with the law. Bilan and Jurickova (2021) define fundamentally effective accounting as the tool to 'beautify' the financial statements.

In their research, Siekelova et al. (2020) found that the larger a company was, the greater the likelihood of manipulation in the company. Additionally, Kliestik et al. (2020) claim that this phenomenon is a set of managerial decisions, which again suggests that this tool affects mainly larger companies. However, Setyoputri and Mardijuwono (2020) refuted these claims, and concluded that a company's size had no effect on how its accounts were managed. The cultural, social, and legal environments under which companies operate influence the decision to manipulate their accounting records. Poradova and Siekelova (2020) divided these factors into two groups: those which relate to government revenue, and those that are internal to companies themselves.

Devos et al. (2021) found, interestingly, that even companies that changed their names suffered in years of low profits, which was an opportunity to use efficient accounting to bring profits at least to a level close to zero. Furthermore, Miller et al. (2021) found this practice in the banking sector.

Azzali et al. (2021) defined earnings management as an abnormal reduction in time resolution. We find this definition interesting, and agree with it because, unlike the use of creativity and manipulation of all or part of accounting records, earnings management focuses on accruals. The definition is supported by models that reveal earnings management and are based on discretionary and non-discretionary accruals; discretionary and non-discretionary accruals remain accruals, whether assets or liabilities.

Mangala and Singla (2021) reported that the issue of earnings management did not provide a sufficient level of information, as their sample was too small to comprehensively examine the profit management of commercial banks in India. This may be because this concept came to the fore only in 2015, as evidenced by the output from the Web of Science database, which is captured in Figure 5. Generally, earnings management is a much younger term than creative accounting, i.e. it is still in its infancy, in 'diapers'.

Research on the use of earnings management was also performed by Mendoza et al. (2021), who analysed the impact of accrual income management and the institutional and financial development of countries on the liquidation of shares in Latin American companies. The results showed that they were again based on accruals. The authors concluded that only institutional development could alleviate the impact of revenue management on the liquidation of these companies. The result is interesting and relevant for future investors.

Based on Suzuki's (2017) research, we learn about the use of fraudulent accounting at Toshiba. In his study, he found that the financial statements had been manipulated, specifically with respect to costs and revenues. Kedia and Philippon (2009) also focused on companies that showed signs of manipulation. In their study, they identified the use of fraudulent accounting, which also related to costs and revenues. Nguyen et al. (2021), in turn, through the fraud triangle, examined the use of fraud and its clarification through disputed accounting transactions; their study involved transactions in Vietnamese companies. Andreff (2019) found that the traditional, capitalist economy was being replaced by a greedy economy. 


\section{Methodology and Data}

In this study, we use bibliometric analysis for the period 1969 - 2021 to capture the following:

- creative accounting,

- earnings management, and

- fraudulent accounting.

We obtained input for the research from the Web of Science database, which is the world's most trusted, independent publisher of full citation databases.

When we researched individual terms, we focused on the keywords that most often related to those terms. Based on these keywords, we established several clusters that were characterised by individual colours. The power, or the most frequently required word in a single term, and thus the principal representative of each cluster, was represented by bullets. The larger the ball, the more the keyword is associated with the issue that is the subject of this study. The table below summarises the key steps that helped create this study.

Table 1: An overview of the steps in the article

\begin{tabular}{|c|c|c|c|c|c|}
\hline Search term used & $\begin{array}{l}\text { Observed } \\
\text { period }\end{array}$ & Search source & $\begin{array}{l}\text { Number of } \\
\text { articles }\end{array}$ & Analyzing via & Program \\
\hline \multicolumn{6}{|l|}{ Creative accounting } \\
\hline Earnings management & $1969-2021$ & $\begin{array}{l}\text { Web of } \\
\text { Science }^{\mathrm{TM}}\end{array}$ & $>18,000$ & $\begin{array}{l}\text { Bibliometric } \\
\text { Analysis }\end{array}$ & VosViewer \\
\hline Fraudulent accounting & & & & & \\
\hline
\end{tabular}

Source: own elaboration

Based on this table, we can describe the individual steps. We chose the Web of Science ${ }^{\mathrm{TM}}$ database as the database for the input data. This database offers many articles that are important for the research.

To attain as much accuracy as possible in the analysis, it is important to analyse as many articles as possible. Therefore, we analysed more than 18,000 articles that were related to concepts such as creative accounting, earnings management, and fraudulent accounting. We could collect this number of articles because we focused on the very beginnings of these concepts, and thus included articles from the very beginning of this issue, i.e. 1969, in the Web of Science database. The period of analysis terminated in 2021, which we considered adequate for critical mass.

Based on the articles obtained, we used the VosViewer program to visualise the scientific activity through which we obtained the desired results.

\section{Results}

We performed the bibliometric analysis using the VOS Viewer tool. Through this approach, we could establish the degree of linkage of articles to their authors from different countries, citations, the number of documents, the occurrence of keywords, and citation maps from various databases, as the program allowed us to process the data from the Web of Science. 


\subsection{Creative accounting}

From the bibliometric analysis (Figure 1), we can see the link between the concept of creative accounting and various other keywords, which are directly linked and together create and complete the essence of creative accounting.

Figure 1: Bibliometric analysis of the concept of creative accounting

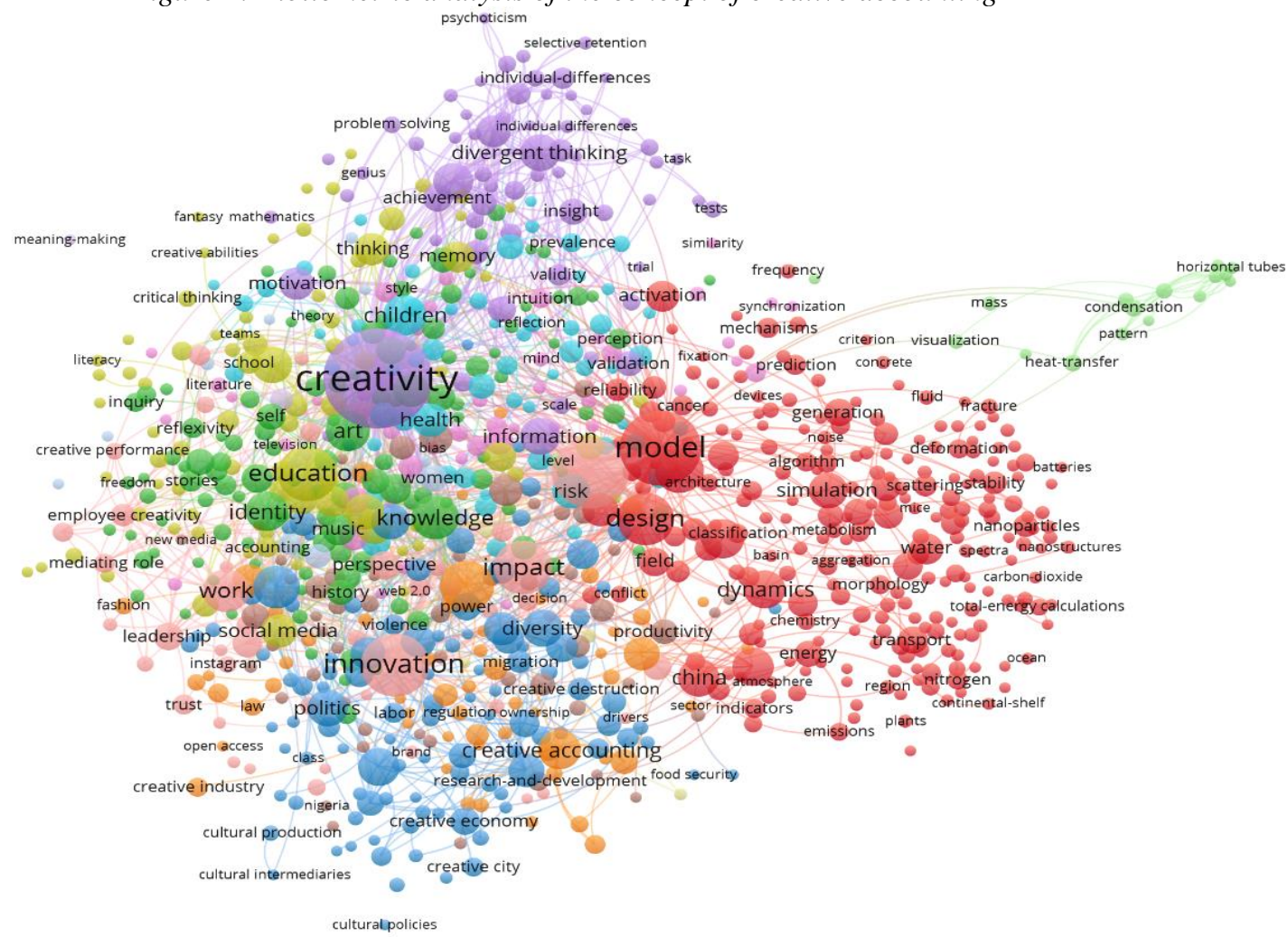

Source: own elaboration

Based on this analysis, the concept of creative accounting can be better understood; additionally, we can also see a strong link with many other concepts that are not known to be associated with this concept. To better understand the picture above, we split the whole picture into a more acceptable number of clusters to capture the most important aspects of creative accounting. We divided the whole bibliometric analysis into 4 clusters: the first represents creativity (blue), the second models (green), the third innovation (yellow), and the last knowledge (red). Based on these clusters, creative accounting may be said to be largely associated with the following terms:

- creativity,

- knowledge,

- innovation, and

- models. 
Figure 2: Bibliometric analysis capturing the most representative concepts of key creative accounting

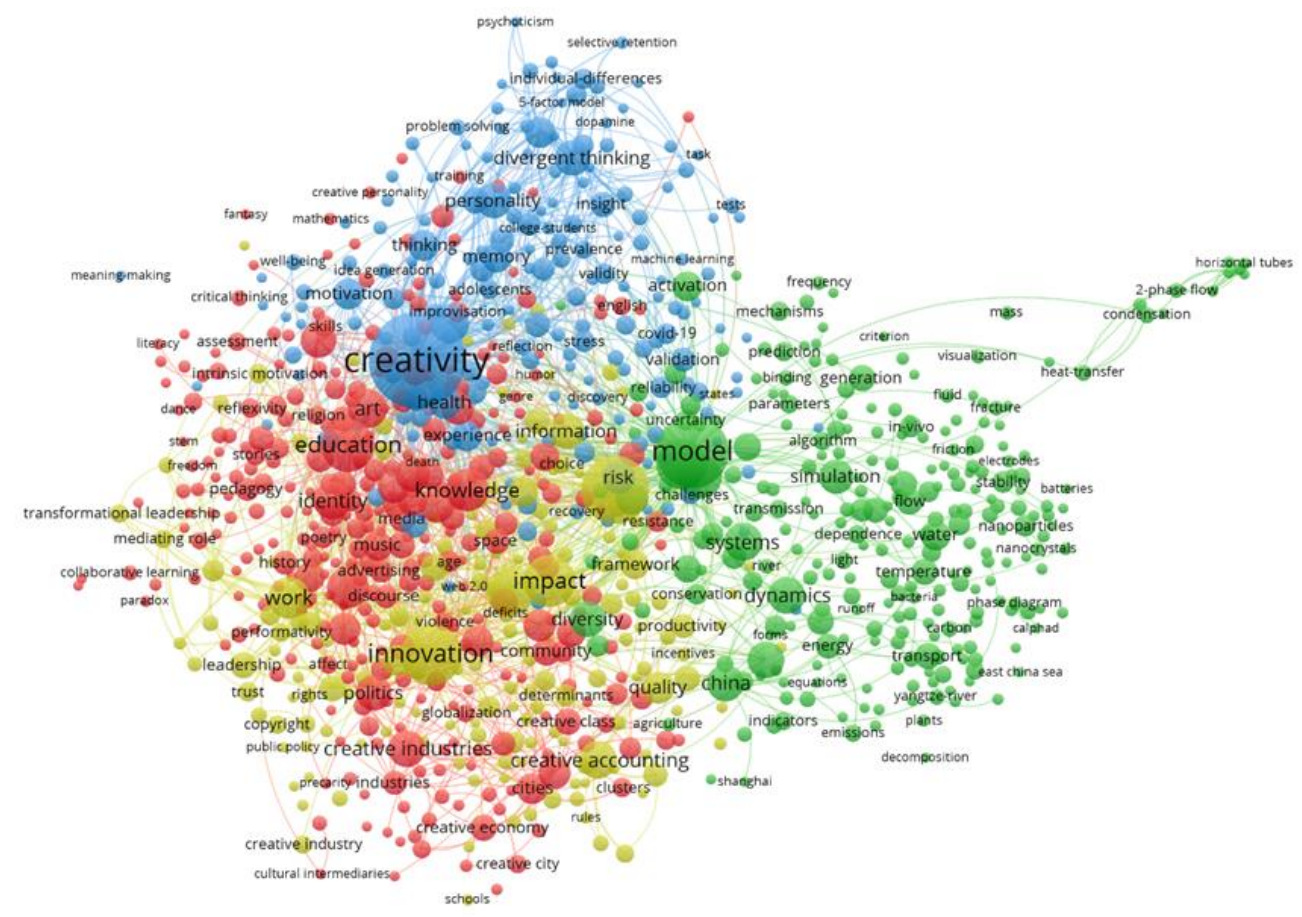

Source: own elaboration

\subsection{Earnings management}

Figure 3 shows a bibliometric analysis of the term, 'earnings management'. Evidently, this concept is intertwined with various interesting concepts that complete the essence of this phenomenon.

Figure 3: Bibliometric analysis of Earnings management



Source: own elaboration 
To capture the most important words that are characteristic of this concept, we specified the clusters in more detail and created another bibliometric analysis.

Figure 4: Bibliometric analysis capturing the most representative concepts of earnings management

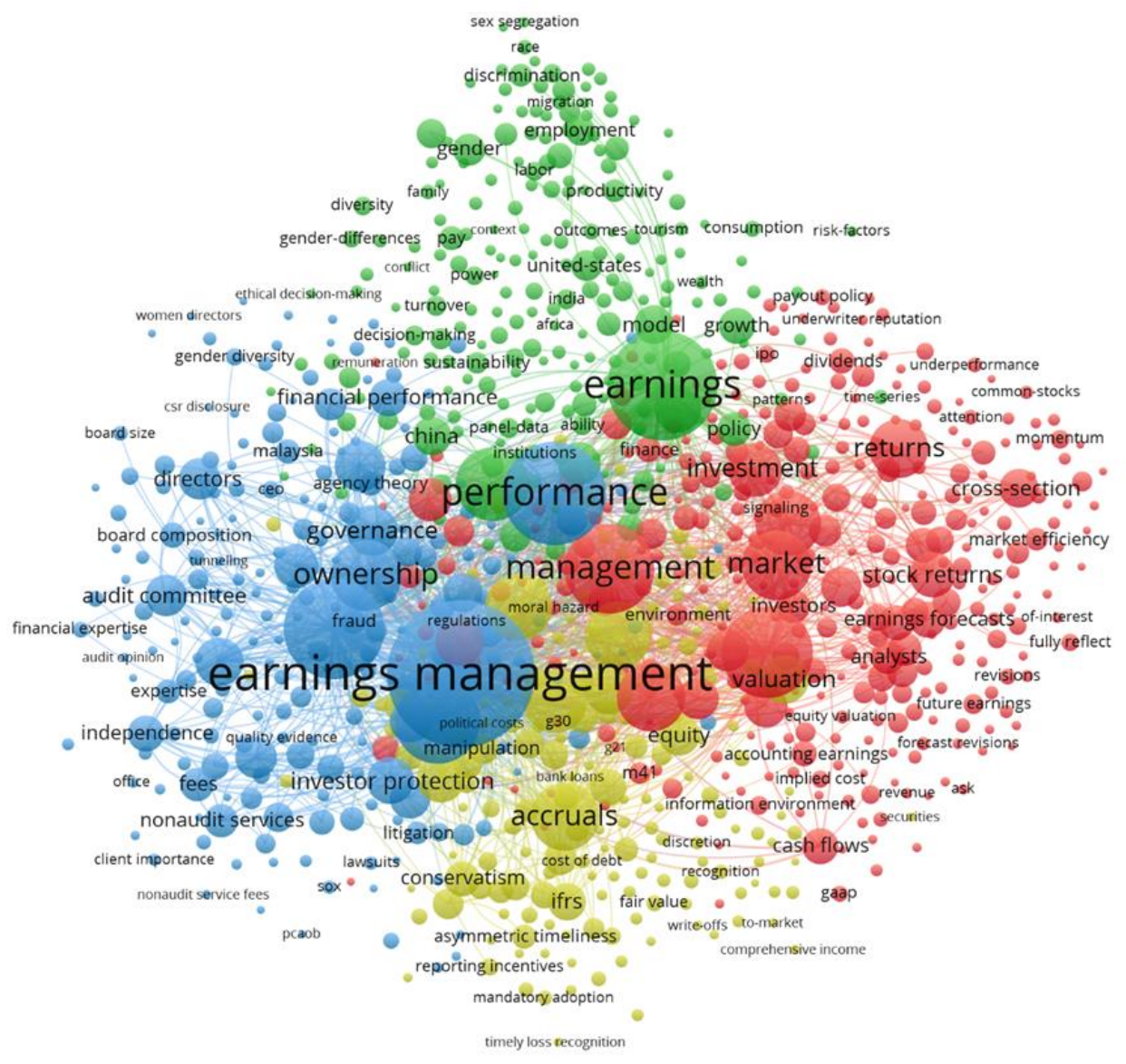

Source: own elaboration

Clearly, as in the case of key accounting, the use of earnings management is represented by a pair of keywords that are further specified by other terms that complete them. In this case, we can see that the very concept of earnings management is characterised by the following words:

- earnings management (blue colour),

- earnings (green colour),

- management (red colour), and

- accruals (yellow colour).

\subsection{Fraudelent accounting}

Based on the data obtained from the Web of Science database, we attempted to create a bibliometric analysis that captured the most important keywords associated with the term, 'fraudulent accounting', or 'Fraudulent Accounting'. 
Figure 5: Bibliometric analysis of Fraudulent Accounting

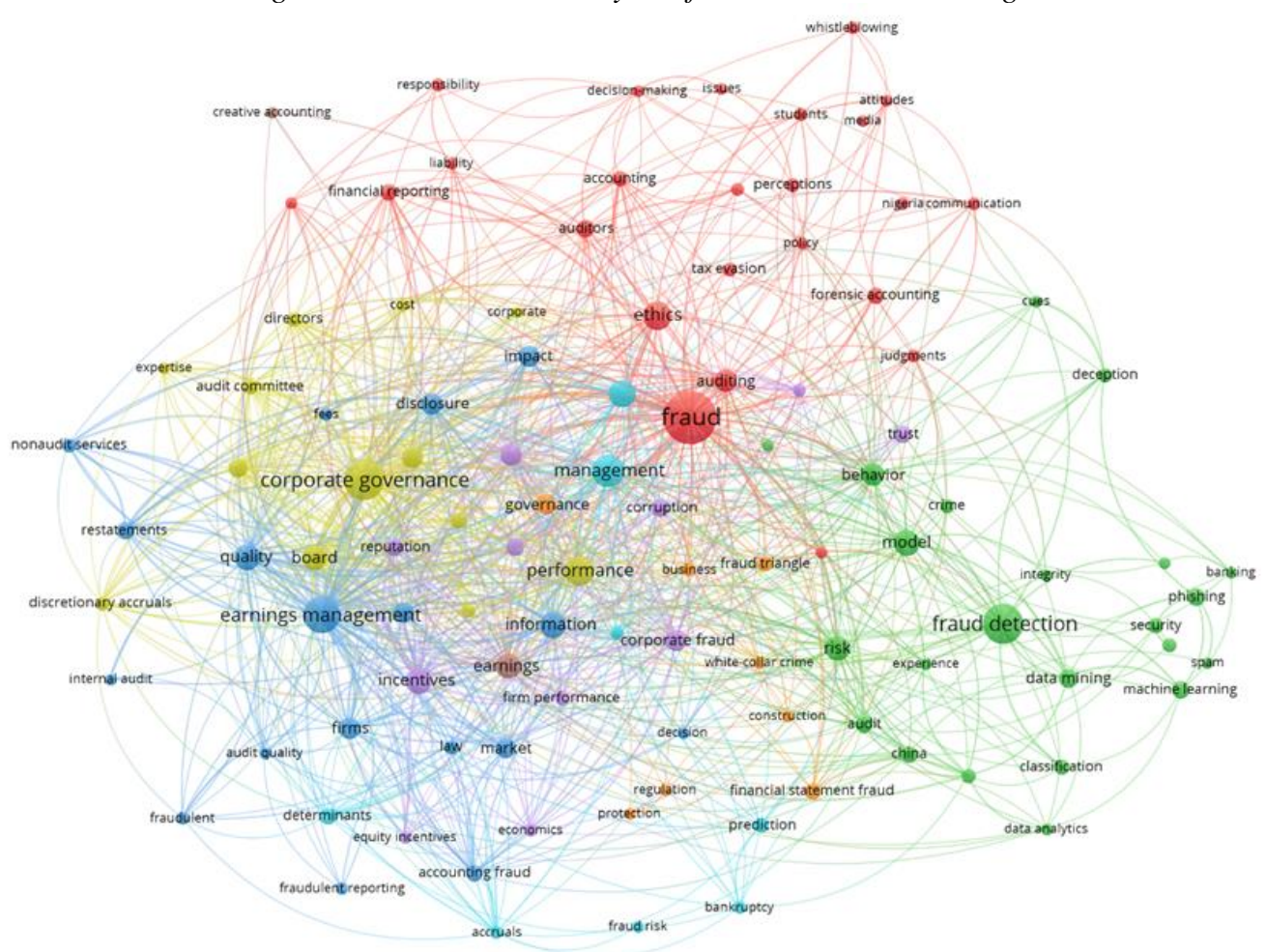

Source: own elaboration

According to the findings and distribution of clusters, we conclude that the term, 'fraudulent accounting', or even 'Fraudulent Accounting', is most represented by the following terms:

- fraud (green colour),

- fraud detection (blue colour), and

- corporate governance (red colour).

We can therefore say that the concept of fraudulent accounting is most often used or associated with the above concepts. 
Figure 6: Bibliometric analysis capturing the most representative concepts of fraudulent accounting

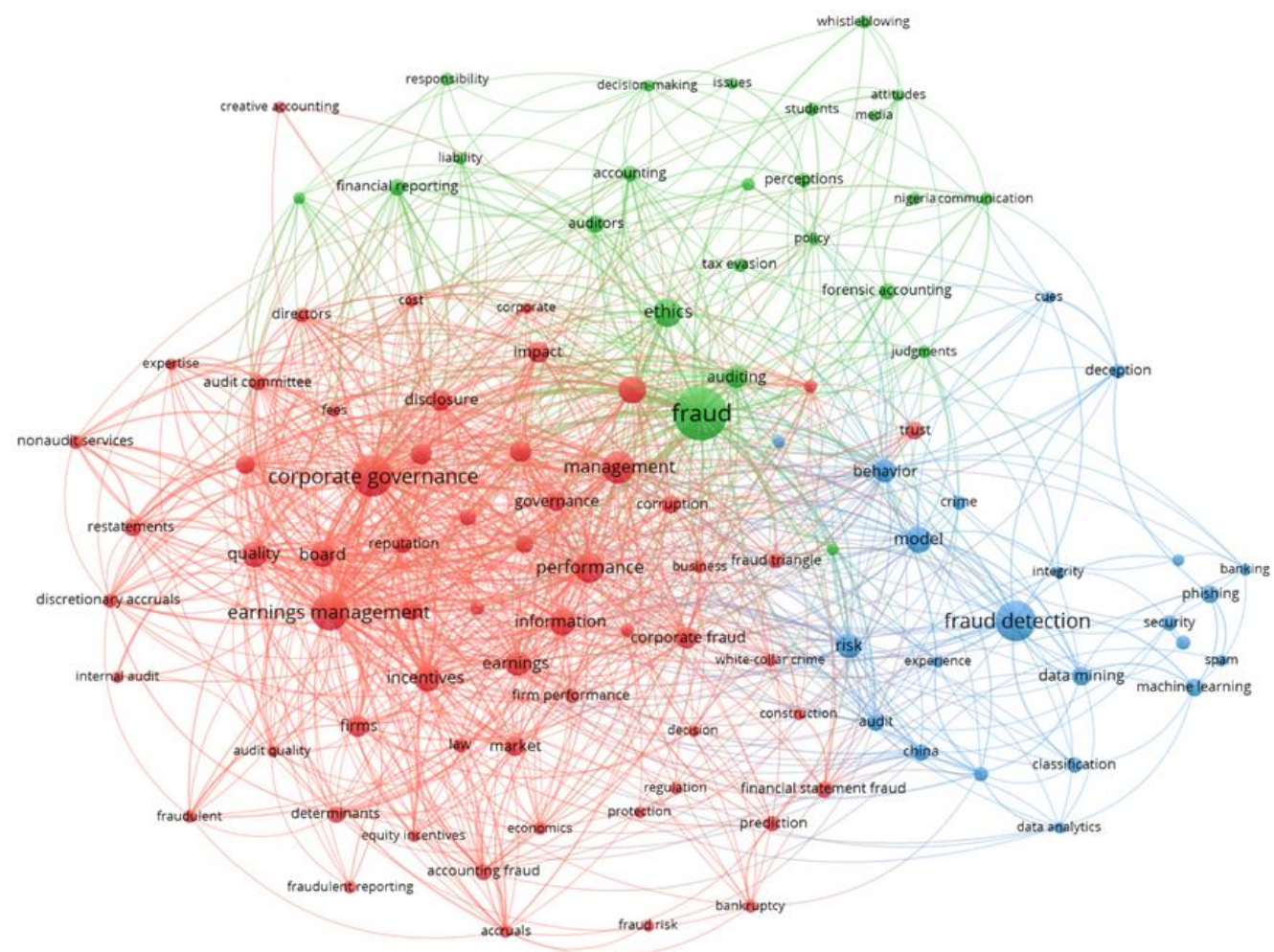

Source: own elaboration

\section{Discussion}

Based on the results, we know that the individual terms characterise the following terms:

- creative accounting - creativity, model, innovation, and knowledge;

- earnings management - earnings, management, and accruals;

- fraudulent accounting - fraud, fraud detection, and corporate governance.

Thus, these results suggest that creative accounting is closely linked to innovations that in turn are directly linked to creativity. To take advantage of these associations, it is necessary for a person who uses creative accounting to have a wide range of knowledge on the topic; additionally, they should be familiar with the models by which these specific accounting models can be unmasked, for them to either circumvent or use them appropriately.

Earnings management is mainly about the use of accruals, which are characteristic of the concept. Through accruals, a company can improve its position, which results in earnings management. These steps can only be performed on the basis of management regulations, which means that the term, 'earnings management', is closely associated with the management of the company, which seeks to satisfy the owner or shareholders, and constantly strives to improve the company's position in the market.

The last research term is fraudulent accounting. This concept is associated with the fraudulent conduct of a person responsible for the normal accounting function. However, such individuals follow the orders of senior managers who are well versed in the management of the company and know the areas in the company that are susceptible to fraud; thus, the senior managers are in the best position to detect any signs of fraudulent activity. 


\section{Conclusions}

Based on our findings, we can identify the most common keywords that are most associated with a term, whether it is creative accounting, earnings management, or fraudulent accounting. Using bibliometric analysis, we could visualise the results. We believe that the results will help other researchers to find appropriate articles on which their studies may be based, or help the general public to navigate the issue; it is often confusing for readers to distinguish between creative accounting, earnings management, and fraudulent accounting. These terms have many similar keywords, while many people mistake them for synonyms, which is not the case. Therefore, based on keywords, we endeavoured to help the scientific community by demonstrating that each concept focused on a different structure of fraud in business accounting.

Author contributions: All authors listed have made a substantial, direct and intellectual contribution to the work, and approved it for publication.

Funding: This research was financially supported by the Slovak Research and Development Agency - Grant Vega 1/0121/20: Research of transfer pricing system as a tool to measure the performance of national and multinational companies in the context of earnings management in conditions of the Slovak Republic and V4 countries.

Data Availability Statement: The data presented in this study are available on request from the corresponding author. The data are not publicly available due to own empirical research of corresponding author.

Conflicts of Interest: The authors declare no conflict of interest.

\section{References}

Adámiková, E., \& Čorejová, T. (2021). Creative accounting and the possibility of its detection in the evaluation of the company by expert. Journal of Risk and Financial Management, 14(7), 327.

Andreff, W. (2019). The unintended emergence of a greed-led economic system. Kybernetes, 48(2), 238-252.

Azzali, S., Mazza, T., Reichelt, K. J., \& Wang, D. (2021). Does mandatory IFRS adoption affect audit hours and the effectiveness to constrain earnings management? Evidence from Italy. AUDITING: A Journal of Practice \& Theory.

Bilan, Y., \& Jurickova, V. (2021). Detection of earnings management by different models. SHS Web of Conferences, 92, EDP Sciences.

Devos, Y., Mumford, J. D., Bonsall, M. B., Glandorf, D. C., \& Quemada, H. D. (2021). Risk management recommendations for environmental releases of gene drive modified insects. Biotechnology Advances, 107807.

Kedia, S., \& Philippon, T. (2009). The economics of fraudulent accounting. The Review of Financial Studies, 22(6), 2169-2199.

Kliestik, T., Valaskova, K., Nica, E., Kovacova, M., \& Lazaroiu, G. (2020). Advanced methods of earnings management: Monotonic trends and change-points under spotlight in the Visegrad countries. Oeconomia Copernicana, 11(2), 371-400.

Kouřilová, J. a Stejskalová, I. (2015). Creative accounting from the perspective of management. 2nd International Multidisciplinary Scientific Conference on Social Sciences and Arts (SGEM 2015), 2, 113-122.

Kovalová, E., \& Michalikova, K. F. (2020). The creative accounting in determining the bankruptcy of Business Corporation. SHS Web of Conferences, 74(01017). EDP Sciences.

Luty, Z. (2019). Know-How transfers in creative accounting. 34th International-Business-InformationManagement-Association (IBIMA) Conference, 9684-9688.

Mangala, D., \& Singla, N. (2021). Do corporate governance practices restrain earnings management in banking industry? Lessons from India. Journal of Financial Reporting and Accounting. 
Mendoza, J. A. M., Ramos, C. L. V., Yelpo, S. M. S., Fuentealba, C. L. D., \& Fuentes-Solís, R. A. (2021). Impact of earnings management on agency costs: Evidence from MILA markets. Baltic Journal of Management, 16(2), 247-275.

Merchant, K. A., \& Rockness, J. (1994). The ethics of managing earnings: An empirical investigation. Journal of Accounting and Public policy, 13(1), 79-94.

Milesi-Ferretti, G. M. (2004). Good, bad or ugly? On the effects of fiscal rules with creative accounting. Journal of Public Economics, 88(1-2), 377-394.

Miller, P., Hopper, T., \& Laughlin, R. (1991). The new accounting history: An introduction. Accounting, Organizations and Society, 16(5-6), 395-403.

Nguyen, L. A., O'Connell, B., Kend, M., \& Vesty, G. (2021). The likelihood of widespread accounting manipulation within an emerging economy. Journal of Accounting in Emerging Economies.

Nývltová, K. (2016). Risk areas of the financial health assessment in agriculture. Agrarian Perspectives XXV. Global and European Challenges for Food Production, Agribusiness and the Rural Economy, Proceedings of the 25th International Scientific Conference, 14-16 September 2016, Prague, Czech Republic (pp. 236-243). Czech University of Life Sciences Prague, Faculty of Economics and Management.

Poradová, M., \& Siekelová, A. (2020). Analysis of factors with impact on earnings and their management in commercial companies. International Scientific Conference on Hradec Economic Days, 10, 649-659.

Setyoputri, L. S., \& Mardijuwono, A. W. (2020). The impact of firm attributes on earnings management. Polish Journal of Management Studies, 22(1), 502-512.

Siekelova, A., Androniceanu, A., Durana, P., \& Michalikova, K. F. (2020). Earnings Management (EM), initiatives and company size: An empirical study. Acta Polytechnica Hungarica, 17(9), 41-56.

Suzuki, D. (2017). Accounting Fraud and accounting standards: The case of Toshiba's Fraudulent accounting. 5th International Conference on Accounting, Auditing, and Taxation (ICAAT), 27, 439-449.

Sylwestrzak, M. (2016). Application of logistic regression to detect the fraudulent financial statements (Zastosowanie regresji logistycznej do wykrywania falszowania sprawozdan finansowych). Problemy Zarzadzania, 14(63), 89-102.

Veiga, J. F., Golden, T. D., \& Dechant, K. (2004). Why managers bend company rules. Academy of Management Perspectives, 18(2), 84-90.

Zemánková, L. (2015). Big bath as a determinant of creative accounting in small and micro enterprises. Acta Universitatis Agriculturae et Silviculturae Mendelianae Brunensis, 63(5), 1779-1785. 